PAPER • OPEN ACCESS

Organism's responses to a long-term inhalation of silica-containing submicron particles of an industrial aerosol

To cite this article: S N Solovyeva et al 2019 IOP Conf. Ser.: Mater. Sci. Eng. 699012054

View the article online for updates and enhancements. 


\title{
Organism's responses to a long-term inhalation of silica- containing submicron particles of an industrial aerosol
}

\author{
S N Solovyeva ${ }^{1}$, B A Katsnelson ${ }^{1}$, M P Sutunkova ${ }^{1}$, L I Privalova ${ }^{1}$, \\ V B Gurvich ${ }^{1}$, I A Minigalieva', T V Slyshkina ${ }^{1}$, I E Valamina ${ }^{2}$, \\ V Ya Shur ${ }^{3}$, I V Zubarev ${ }^{3}$ and D K Kuznetsov ${ }^{3}$
}

${ }^{1}$ Ekaterinburg Medical Research Centre for Prophylaxis and Health Protection in Industrial Workers, 620014 Ekaterinburg, Russia

${ }^{2}$ Central Research Laboratory of the Ural Medical University, 620028 Ekaterinburg, Russia

${ }^{3}$ School of Natural Sciences and Mathematics, Ural Federal University, 620000 Ekaterinburg, Russia

solovyevasn@ymrc.ru

\begin{abstract}
Female white rats were exposed during up to 6 months 5 times a week, $4 \mathrm{hr}$ per day in a "nose only" inhalation device to an aerosol containing predominantly submicron (nanoscale included) particles of amorphous silica in the concentration $2.6 \pm 0.6$ or $10.6 \pm 2.1 \mathrm{mg} / \mathrm{m}^{3}$. In an auxiliary experiment with a single-shot intratracheal instillation of these particles, it was shown that they induced a pulmonary cell response comparable with that to highly cytotoxic and fibrogenic standard quartz powder $\mathrm{DQ}_{12}$. However, in the long-term inhalation test, the studied aerosol proved to be of very low systemic toxicity and fibrogenicity. This paradox may be explained by low $\mathrm{SiO}_{2}$ retention in lungs and other organs due to a relatively high in vivo solubility of these nanoparticles. Nevertheless, their genotoxic action and transnasal penetration into the brain should make one give a cautious overall assessment of this aerosol as an occupational or environmental hazard.
\end{abstract}

\section{Introduction}

While engineered $\mathrm{SiO}_{2}$ nanoparticle toxicity is being widely investigated, mostly on cell lines or in acute animal experiments [1-9], and a lot of others, the practical importance of industrial condensation aerosols with a high $\mathrm{SiO}_{2}$ particle content and the theoretical interest in it seems to be neglected. Thus, long-term inhalation exposure to nano- $\mathrm{SiO}_{2}$ has not been, as far as we know, undertaken in experimental nanotoxicology research.

\section{Experimental}

Outbred female white rats were exposed for 3 or 6 months, 5 times a week, $4 \mathrm{hr}$ a day to an aerosol containing $72 \%$ amorphous silica predominantly submicron particles at an exposure concentration of $2.6 \pm 0.6$ or $10.6 \pm 2.1 \mathrm{mg} / \mathrm{m}^{3}$. This material (Fig. 1a) had been collected from the flue-gas ducts of electric ore smelting furnaces producing elemental silicon, subsequently sieved through a $<2 \mu \mathrm{m}$ screen and re-dispersed in airflow (Fig. 1b) to feed a computerized "nose only" inhalation system (Fig. 2). 


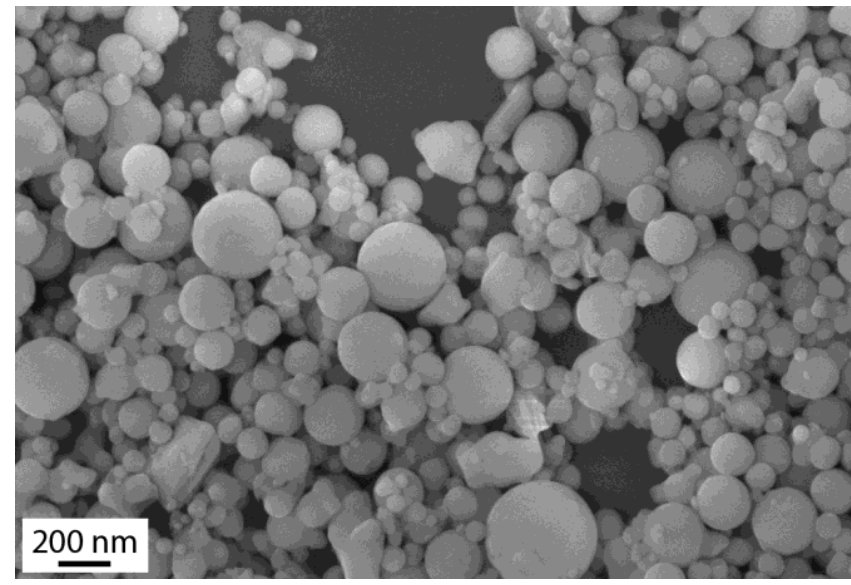

(a)

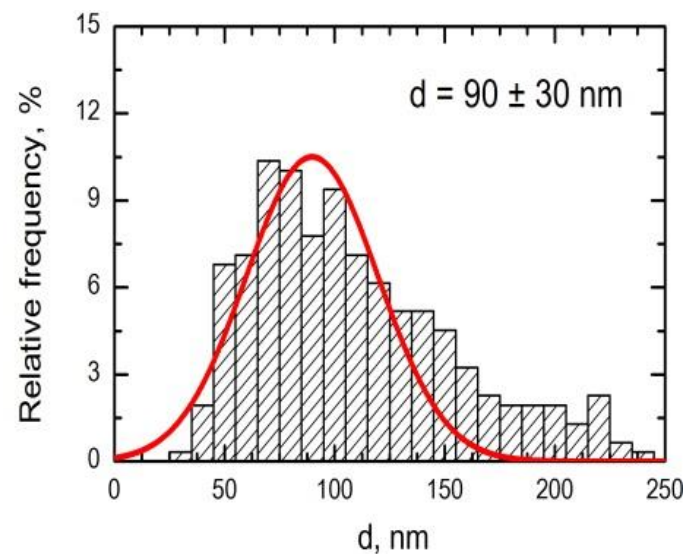

(b)

Figure 1. Particles of the powder collected in the flue gas duct from the hood over a silicon smelting ore-thermal furnace and sieved through $\mathrm{a}<2 \mu \mathrm{m}$ screen. (a) SEM image, (b) particle size distribution.

Preliminarily, we carried out an experiment to study the response of the lower airways free cells obtained from rats exposed, $24 \mathrm{~h}$ before bronchoalveolar lavage, to a single-shot intratracheal instillation of the same particles suspended in normal saline in comparison with the response to the highly cytotoxic and fibrogenic standard quartz dust $\mathrm{DQ}_{12}$. A batch of each powder was incubated during $24 \mathrm{~h}$ at $37^{\circ} \mathrm{C}$ together with either the normal saline, or the Ringer-Locke's solution, or the cellfree bronchoalveolar lavage fluid (BALF) supernatant. Samples of each system were taken at several time points and analysed for the Si content with the help of atomic absorption spectrometry (AAS).

\section{Results and discussion}

Judging by a 3-4-fold increase in the total cell count of the BALF after intratracheal instillation of particles due to enhanced recruitment of alveolar macrophages (AM) and, especially, of neutrophil leukocytes (NL) to the lower airways free surface (Table 1), the cytotoxicity of Nano-Silica Containing Aerosol (NSCA) investigated and that of quartz $\mathrm{DQ}_{12}$ are quite similar.

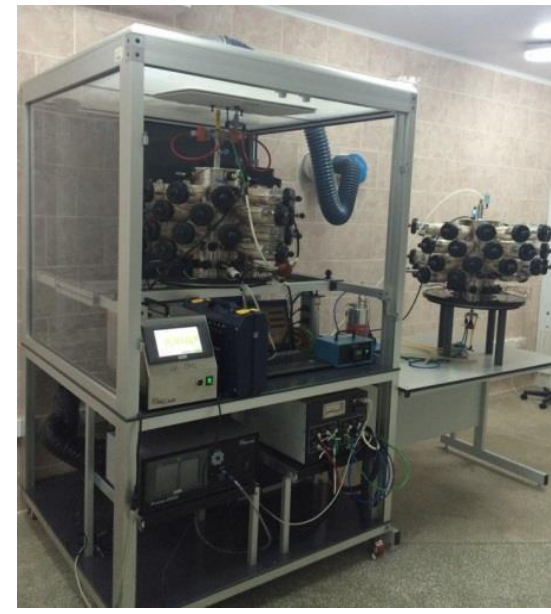

(a)

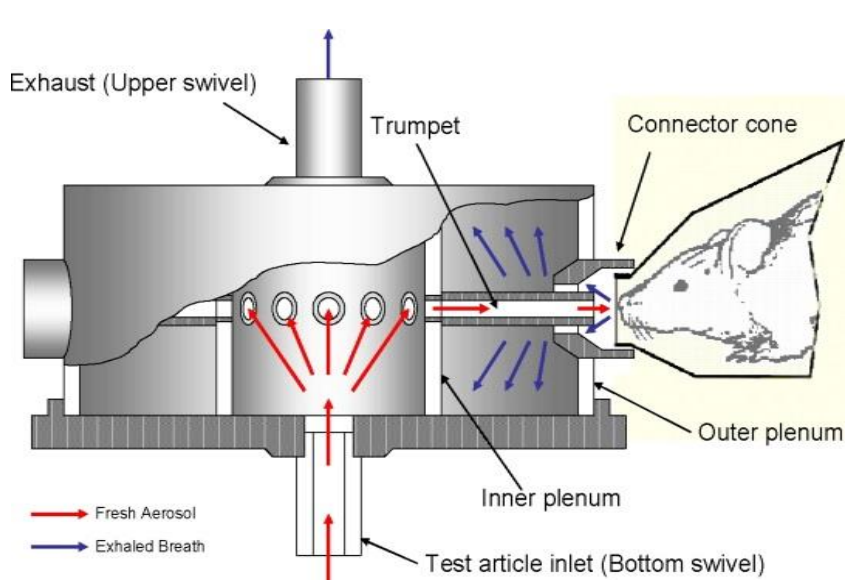

(b)

Figure 2. (a) General view of the experimental setup (photographed with the front chamber doors removed). Next to the exposure unit, a similar system setup for sham exposure of control rats is seen. (b) Diagram of aerosol flows in the "nose only" inhalation exposure system (courtesy CH Technology, USA). 
Table 1. Number of cells in the bronchoalveolar lavage fluid (BALF) 24 hours after intratracheal instillation of NSCA pr DQ 12 particle suspensions administered to rats at a dose of $7 \mathrm{mg}$ in $1 \mathrm{~mL}$ normal saline ( $\mathrm{x} \pm$ s.e.).

$N B$ : *statistically significant difference from the control group $(\mathrm{P}<0.05$ by Student's t-test).

\begin{tabular}{|c|c|c|c|c|}
\hline \multirow{2}{*}{$\begin{array}{c}\text { What was } \\
\text { instilled: }\end{array}$} & \multicolumn{3}{|c|}{ Number of cells * 10 } & \multirow{2}{*}{ NL/AM } \\
\cline { 2 - 4 } & Total & $\begin{array}{c}\text { Alveolar macro- } \\
\text { phages (AM) }\end{array}$ & $\begin{array}{c}\text { Neutrophil } \\
\text { leukocytes (NL) }\end{array}$ & \\
\hline NSCA & $5.85 \pm 0.56^{*}$ & $3.03 \pm 0.66$ & $2.86 \pm 0.79^{*}$ & $2.24 \pm 1.16^{*}$ \\
\hline $\mathrm{DQ}_{12}$ & $7.44 \pm 1.30^{*}$ & $3.79 \pm 0.94^{*}$ & $3.10 \pm 0.80^{*}$ & $1.69 \pm 0.64^{*}$ \\
\hline $\begin{array}{c}\text { Normal saline } \\
\text { control group) }\end{array}$ & $1.96 \pm 0.29$ & $1.49 \pm 0.28$ & $0.52 \pm 0.24$ & $0.37 \pm 0.16$ \\
\hline
\end{tabular}

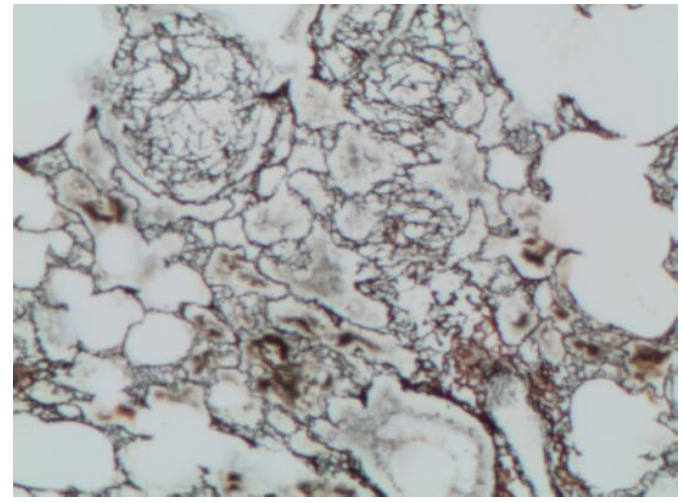

(a)

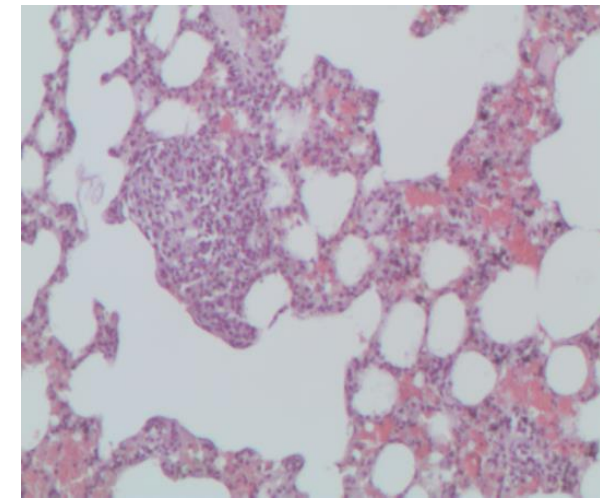

(b)

Figure 3. Rat lungs after inhalation exposure to the NSCA at the concentration of $10.6 \mathrm{mg} / \mathrm{m}^{3}$ during 6 months. (a) Focal coarsening of the argyrophylic framework of the lung tissue and appearance of a net of thin argyrophylic fibres within a macrophagal-lymphocytic nodule. (b) Alveolar septa are thickened, with lymphocytic infiltration, but round macrophage-lymphocytic clusters without detectable collagen fibres within or around them seen in this preparation occur as solitary observations only. Hematoxylin and eosin staining, magnification X50.

Table 2. Some indices for rat lungs status after inhalation exposure to particles of NSCA (X \pm s.e.). $N B$ : *statistically significantly difference from corresponding control value ( $\mathrm{p}<0.05$ by Student's t-test); -statistically significantly difference from the low-exposure group of the same exposure period ( $\mathrm{p}<0.05$ by Student's t-test).

\begin{tabular}{|c|c|c|c|c|c|c|}
\hline \multirow[b]{2}{*}{ Indices } & \multicolumn{3}{|c|}{3 months } & \multicolumn{3}{|c|}{6 months } \\
\hline & \begin{tabular}{|l} 
Controls \\
\end{tabular} & \begin{tabular}{|c|} 
NSCA \\
$2.6 \mathrm{mg} / \mathrm{m}^{3}$
\end{tabular} & $\begin{array}{c}\text { NSCA } \\
10.6 \mathrm{mg} / \mathrm{m}^{3}\end{array}$ & Controls & $\begin{array}{c}\text { NSCA } \\
2.6 \mathrm{mg} / \mathrm{m}^{3}\end{array}$ & $\begin{array}{c}\text { NSCA } \\
10.6 \mathrm{mg} / \mathrm{m}^{3}\end{array}$ \\
\hline $\begin{array}{l}\text { Dry lung mass, } \\
\mathrm{g} / 100 \mathrm{~g} \text { body mass }\end{array}$ & $\begin{array}{c}0.08 \\
\pm 0.01\end{array}$ & $\begin{array}{c}0.08 \\
\pm 0.01\end{array}$ & $\begin{array}{c}0.09 \\
\pm 0.01\end{array}$ & $\begin{array}{c}0.17 \\
\pm 0.02\end{array}$ & $\begin{array}{c}0.17 \\
\pm 0.02\end{array}$ & $\begin{array}{c}0.16 \\
\pm 0.01\end{array}$ \\
\hline $\begin{array}{l}\text { Total lipid content of lungs, } \\
\mathrm{mg}\end{array}$ & $\begin{array}{l}33.82 \\
\pm 2.74\end{array}$ & $\begin{array}{l}31.84 \\
\pm 2.98\end{array}$ & $\begin{array}{l}37.66 \\
\pm 4.57\end{array}$ & $\begin{array}{l}68.02 \\
\pm 5.63\end{array}$ & $\begin{array}{c}36.98 \\
\pm 4.81^{*}\end{array}$ & $\begin{array}{l}60.64 \\
\pm 4.56\end{array}$ \\
\hline $\begin{array}{l}\text { Hydroxyproline content of } \\
\text { lungs, } \mu \mathrm{g}\end{array}$ & $\begin{array}{c}2060 \\
\pm 85\end{array}$ & $\begin{array}{c}4978 \\
\pm 1187^{*}\end{array}$ & $\begin{array}{c}4641 \\
\pm 1022 *\end{array}$ & $\begin{array}{l}4112 \\
\pm 578\end{array}$ & $\begin{array}{l}3048 \\
\pm 533\end{array}$ & $\begin{array}{c}6142 \\
\pm 946 \bullet\end{array}$ \\
\hline $\begin{array}{l}\text { Hydroxyproline content of } \\
\text { lungs, } \mu \mathrm{g} / 100 \mathrm{~g} \text { body mass }\end{array}$ & $\begin{array}{l}776 \\
\pm 42\end{array}$ & $\begin{array}{c}1898 \\
\pm 460^{*}\end{array}$ & $\begin{array}{l}1711.9 \\
\pm 381^{*}\end{array}$ & $\begin{array}{l}1653 \\
\pm 209\end{array}$ & $\begin{array}{l}1146 \\
\pm 209\end{array}$ & $\begin{array}{l}2227 \\
\pm 342\end{array}$ \\
\hline
\end{tabular}


Table 3. $\mathrm{SiO}_{2}$ content of the rat organs, blood and excreta $(\mathrm{x} \pm$ s.e. $)$.

$N B:{ }^{1}$ Determined in each group of rats' pooled tissue, divided by the number of rats in the group;

"Statistically significantly different from the control value for the same exposure period;

${ }^{+}$Statistically significantly different from the index obtained for the same exposure period at the lower concentration;

${ }^{\circledR}$ Statistically significantly different from the value obtained for the previous exposure period at the same concentration $(\mathrm{p}<0.05$ by Student's t-test $)$.

\begin{tabular}{|c|c|c|c|c|c|c|c|c|c|c|}
\hline \multirow{2}{*}{$\begin{array}{l}\text { Exposure } \\
\text { period, } \\
\text { months }\end{array}$} & \multirow[t]{2}{*}{ Group } & \multicolumn{6}{|c|}{ Organs, mg } & \multirow{2}{*}{$\begin{array}{c}\text { Blood, } \\
\text { mg/L }\end{array}$} & \multirow{2}{*}{$\begin{array}{l}\text { Urine, } \\
\text { mg/L }\end{array}$} & \multirow{2}{*}{$\begin{array}{c}\text { Feces, } \\
\mathrm{mg} / \mathrm{g}\end{array}$} \\
\hline & & lungs & $\begin{array}{c}\text { lungs- } \\
\text { associated } \\
\text { lymph } \\
\text { nodes }\end{array}$ & Liver & kidneys & spleen & brain & & & \\
\hline \multicolumn{11}{|c|}{ Exposure concentration of NSCA $2.6 \mathrm{mg} / \mathrm{m}^{3}$} \\
\hline \multirow[t]{2}{*}{3} & Exposed & $\begin{array}{l}0.11 \pm \\
0.02 * \\
\end{array}$ & 0.01 & $\begin{array}{l}0.02 \pm \\
0.00 *\end{array}$ & $\begin{array}{l}0.03 \pm \\
0.00^{*} \\
\end{array}$ & \begin{tabular}{|l|}
$0.02 \pm$ \\
0.00 \\
\end{tabular} & \begin{tabular}{|l|}
$0.02 \pm$ \\
0.00 \\
\end{tabular} & $\begin{array}{l}0.39 \pm \\
0.16^{*}\end{array}$ & $\begin{array}{l}1.47 \pm \\
0.21^{*} \\
\end{array}$ & $\begin{array}{l}2.18 \pm \\
0.12 *\end{array}$ \\
\hline & Control & $\begin{array}{l}0.02 \pm \\
0.01 \\
\end{array}$ & 0.00 & $\begin{array}{l}0.01 \pm \\
0.01\end{array}$ & $\begin{array}{l}0.01 \pm \\
0.01 \\
\end{array}$ & \begin{tabular}{|l|}
$0.02 \pm$ \\
0.01 \\
\end{tabular} & \begin{tabular}{|l|}
$0.01 \pm$ \\
0.00 \\
\end{tabular} & $\begin{array}{l}0.24 \pm \\
0.06\end{array}$ & \begin{tabular}{|l|}
$0.44 \pm$ \\
0.07 \\
\end{tabular} & $\begin{array}{l}1.36 \pm \\
0.10\end{array}$ \\
\hline \multirow[t]{2}{*}{6} & Exposed & \begin{tabular}{|l}
$0.20 \pm$ \\
$0.01^{*+}$ \\
\end{tabular} & 0.06 & $\begin{array}{l}0.04 \pm \\
0.01^{*+}\end{array}$ & \begin{tabular}{|l|}
$0.04 \pm$ \\
$0.01 *+$
\end{tabular} & $\begin{array}{l}0.05 \pm \\
0.01 *+ \\
\end{array}$ & \begin{tabular}{|l|}
$0.02 \pm$ \\
0.00 \\
\end{tabular} & $\begin{array}{l}0.46 \pm \\
0.04^{*+} \\
\end{array}$ & $\begin{array}{l}1.68 \pm \\
0.07 *+ \\
\end{array}$ & $\begin{array}{l}2.32 \pm \\
0.28 *\end{array}$ \\
\hline & Control & $\begin{array}{l}0.04 \pm \\
0.006\end{array}$ & 0.01 & $\begin{array}{l}0.01 \pm \\
0.002\end{array}$ & $\begin{array}{l}0.01 \pm \\
0.001\end{array}$ & $\begin{array}{l}0.02 \pm \\
0.003\end{array}$ & $\begin{array}{l}0.01 \pm \\
0.00\end{array}$ & $\begin{array}{l}0.27 \pm \\
0.04\end{array}$ & $\begin{array}{l}0.44 \pm \\
0.07\end{array}$ & $\begin{array}{l}1.38 \pm \\
0.08\end{array}$ \\
\hline \multicolumn{11}{|c|}{ Exposure concentration of NSCA $10,6 \mathrm{mg} / \mathrm{m}^{3}$} \\
\hline \multirow[t]{2}{*}{3} & Exposed & $\begin{array}{l}0.63 \pm \\
0.07 * @ \\
\end{array}$ & 0.02 & $\begin{array}{l}0.03 \pm \\
0.00^{*} @ \\
\end{array}$ & $\begin{array}{l}0.04 \pm \\
0.01 * @ \\
\end{array}$ & $\begin{array}{l}0.06 \pm \\
0.01 * @\end{array}$ & $\begin{array}{l}0.02 \pm \\
0.00 \\
\end{array}$ & $\begin{array}{l}0.60 \pm \\
0.14^{*}\end{array}$ & $\begin{array}{l}4.57 \pm \\
0.23^{* @} \\
\end{array}$ & $\begin{array}{l}7.24 \pm \\
0.30 * @ \\
\end{array}$ \\
\hline & Control & \begin{tabular}{|l}
$0.02 \pm$ \\
0.01 \\
\end{tabular} & 0.00 & $\begin{array}{l}0.01 \pm \\
0.01\end{array}$ & $\begin{array}{l}0.01 \pm \\
0.01 \\
\end{array}$ & $\begin{array}{l}0.02 \pm \\
0.01\end{array}$ & $\begin{array}{l}0.01 \pm \\
0.00 \\
\end{array}$ & $\begin{array}{l}0.24 \pm \\
0.06\end{array}$ & \begin{tabular}{|l}
$0.44 \pm$ \\
0.07 \\
\end{tabular} & $\begin{array}{l}1.36 \pm \\
0.10\end{array}$ \\
\hline \multirow[t]{2}{*}{6} & Exposed & \begin{tabular}{|l}
$0.74 \pm$ \\
$0.05^{*+@}$ \\
\end{tabular} & 0.06 & \begin{tabular}{|l|}
$0.06 \pm$ \\
$0.01^{*+@}$ \\
\end{tabular} & \begin{tabular}{|l|l}
$0.07 \pm$ \\
$0.01 *+@$ \\
\end{tabular} & $\begin{array}{l}0.07 \pm \\
0.00^{*+@} \\
\end{array}$ & \begin{tabular}{|l}
$0.02 \pm$ \\
0.00 \\
\end{tabular} & $\begin{array}{l}0.71 \pm \\
0.05^{*+@} \\
\end{array}$ & \begin{tabular}{|l|l}
$3.06 \pm$ \\
$0.11^{*+@}$ \\
\end{tabular} & $\begin{array}{l}4.39 \pm \\
0.53 *+@ \\
\end{array}$ \\
\hline & Control & \begin{tabular}{|l}
$0.04 \pm$ \\
0.01 \\
\end{tabular} & 0.01 & $\begin{array}{l}0.01 \pm \\
0.00 \\
\end{array}$ & \begin{tabular}{|l}
$0.01 \pm$ \\
0.00 \\
\end{tabular} & $\begin{array}{l}0.02 \pm \\
0.00 \\
\end{array}$ & $\begin{array}{l}0.01 \pm \\
0.00 \\
\end{array}$ & $\begin{array}{l}0.27 \pm \\
0.04 \\
\end{array}$ & $\begin{array}{l}0.44 \pm \\
0.07 \\
\end{array}$ & $\begin{array}{l}1.38 \pm \\
0.08 \\
\end{array}$ \\
\hline
\end{tabular}

However, under long-term inhalation exposures, the NSCA proved to be of a very low systemic toxicity as assessed with a lot of functional and biochemical indices, and of a negligible pulmonary fibrogenicity as assessed both morphologically (Fig. 3) and biochemically (Table 2).

As can be seen from Table 3, the AAS- determined silica content of the lungs and lungs-associated lymph nodes is substantially higher than in the controls, this increase being dependent on both the level and the duration of the inhalation exposure, which dependences confirm its causal relationship with the latter.

However, according to Ref. [10], approximately the same extent of retention of $\mathrm{SiO}_{2}$ in rat lungs $(0.550 \mathrm{mg})$ was observed over 6 months under a similar inhalation exposure to standard quartz dust $D_{12}$ at a concentration of $1 \mathrm{mg} / \mathrm{m}^{3}$, which is 10 times lower than in our experiment with the NSCA. In other words, if calculated per unit concentration of aerosol in the air, the accumulated mass of particles in the lungs under chronic inhalation exposure to NSCA is approximately 10 times less than that under similar inhalation exposure to quartz dust $\mathrm{DQ}_{12}$.

The most consistent explanation of this phenomenon (which, in its turn, is a sufficient explanation of weak silica-induced pathology) is the dissolution of submicron (nanoscale, in particular) silica particles in vivo, especially in the lining fluid of the pulmonary area, on which they deposit when inhaled. This mechanism was modelled by us in vitro by a noticeable solubilisation of particles in the BALF of intact rats.

Even though the scanning transmission electron microscopy (STEM) confirmed that NSCA particles are retained in the lungs (Fig. 4), this retention was evidently not sufficient to cause any essential pathological changes in the pulmonary tissue. 


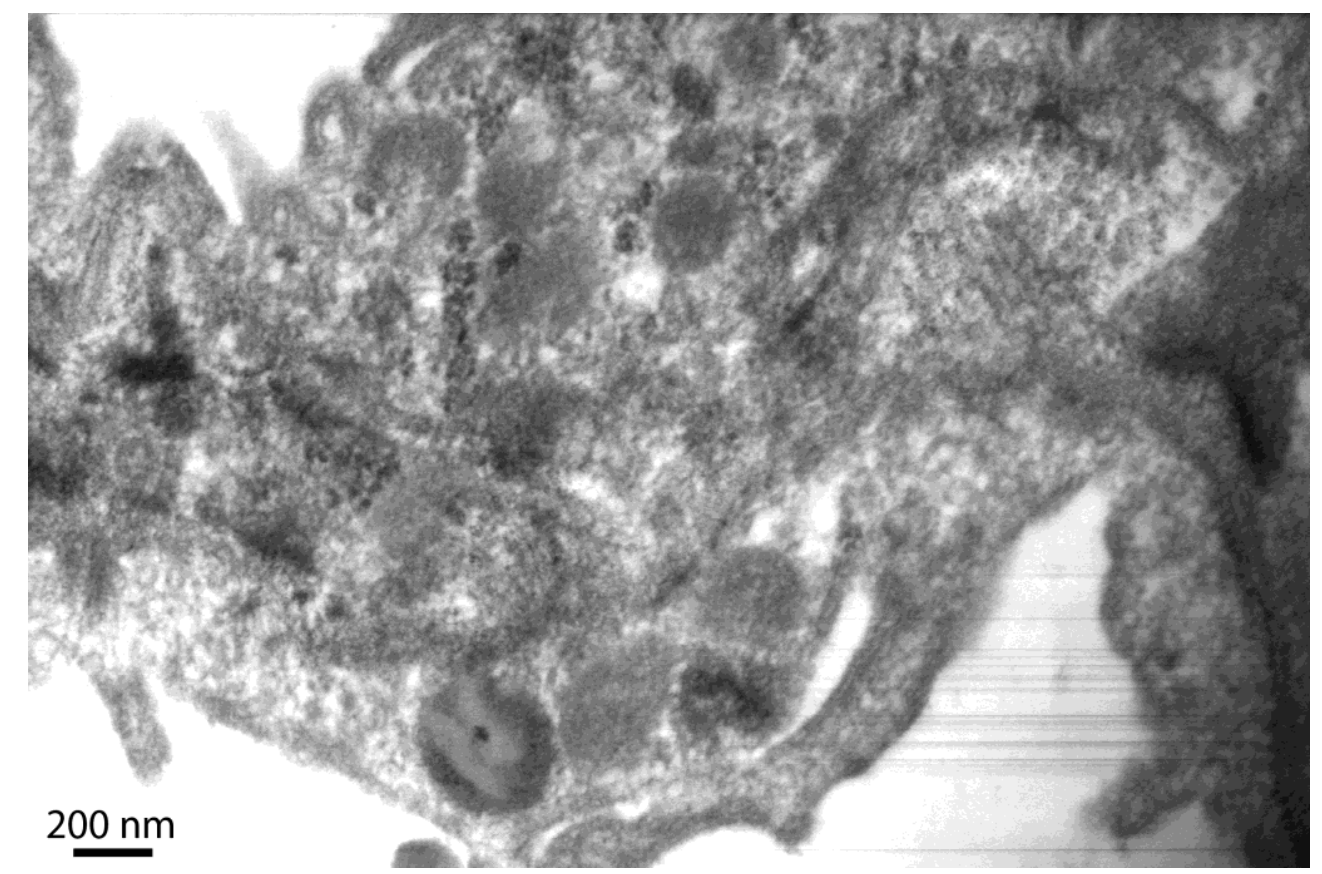

Figure 4. Nanoparticles within a type I alveolocytes of a rat exposed to the NSCA at the concentration of $10.6 \mathrm{mg} / \mathrm{m}^{3}$ during 3 months. STEM image.

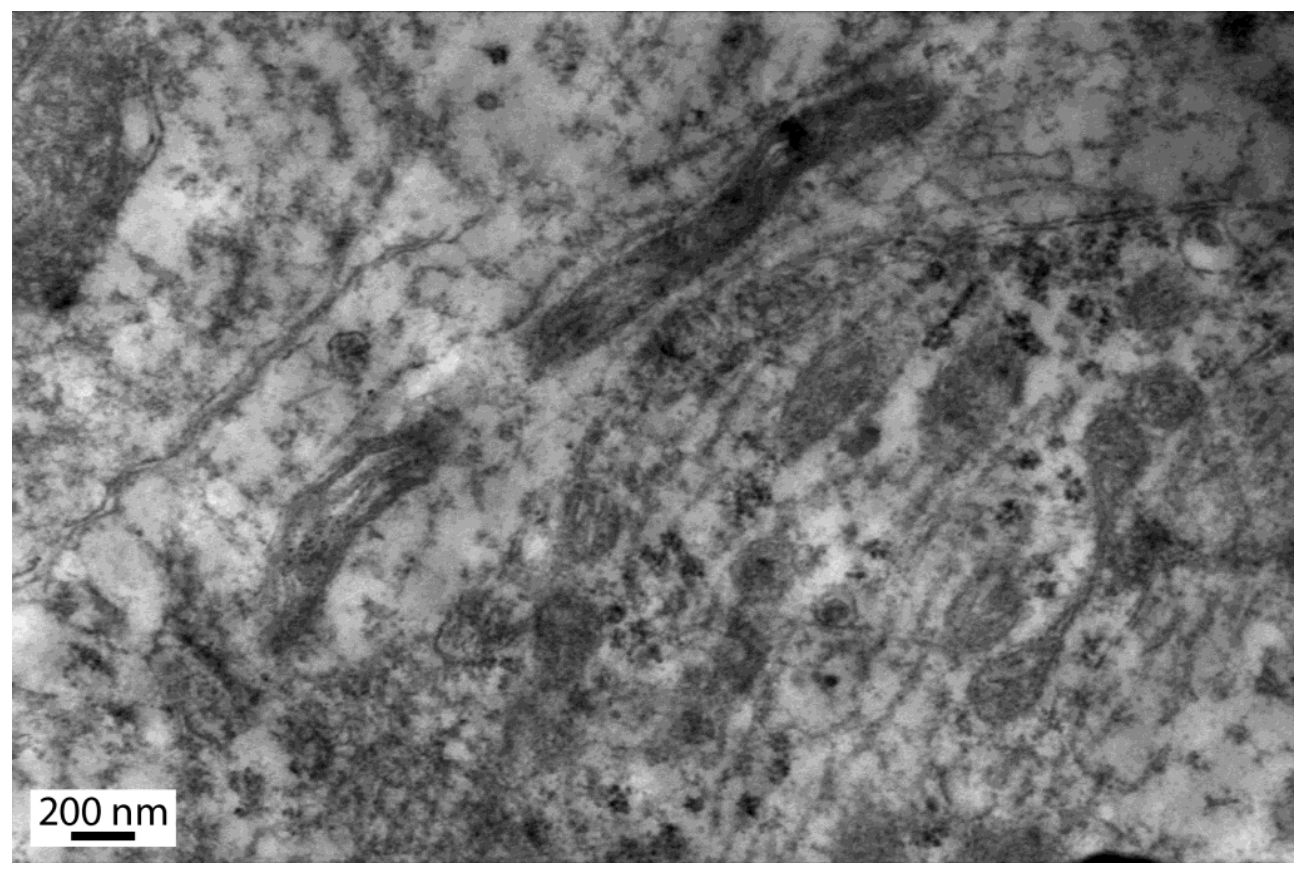

Figure 5. Nanoparticles in the neuron body under inhalation exposure to NSCA at the concentration of $2.6 \mathrm{mg} / \mathrm{m}^{3}$ during 3 months. STEM image.

The ability of inhaled nanoparticles initially deposited in the nasal passages to penetrate along the olfactory nerve fibres into the olfactory area of the brain known from the literature [11-13] has been confirmed in our previous experiment with nano- $\mathrm{Fe}_{2} \mathrm{O}_{3}$ as well [14]. As follows from Figure 5, even in the rats that were exposed to the lowest concentration of the NSCA we revealed a considerable number of nanoscale electron-dense round formations in some neurons of this area. These formations are most likely to be nanoparticles of the aerosol under study. 
Table 4. Genomic DNA fragmentation coefficient for blood and bone marrow cells of rats exposed to the NSCA per inhalation during 6 months (RAPD-test) $(x \pm$ s.e. $)$

$N B$ * Statistically significant difference from corresponding control value;

-Statistically significant difference from the low-exposure group $(\mathrm{p}<0.05$ by Student's t-test).

\begin{tabular}{|c|c|c|c|}
\hline \multirow{2}{*}{ Cells } & \multirow{2}{*}{ Controls } & \multicolumn{2}{|c|}{ Exposure level } \\
\cline { 3 - 4 } & & $\mathbf{2 . 6} \mathbf{~ m g} / \mathbf{m}^{\mathbf{3}}$ & $\mathbf{1 0 . 6} \mathbf{~ m g} / \mathbf{m}^{\mathbf{3}}$ \\
\hline Nucleated blood cells & $0.4240 \pm 0.0005$ & $0.4622 \pm 0.0004^{*}$ & $0.4704 \pm 0.0005^{*} \bullet$ \\
\hline Bone marrow & $0.3995 \pm 0.0005$ & $0.4043 \pm 0.0003^{*}$ & $0.4316 \pm 0.0003^{*}$ \\
\hline
\end{tabular}

As can been seen from Table 4, the enhanced fragmentation of the genomic DNA was found in both nucleated blood cells and bone marrow cells, the latter clearly displaying the dependence of this effect on the exposure level.

\section{Conclusion}

The silica (mostly amorphous) containing submicron particles with a prevailing proportion of those in the nanoscale range induce, when instilled intratracheally, a pulmonary cell response comparable with that to highly cytotoxic and fibrogenic standard quartz powder $\mathrm{DQ}_{12}$. Nevertheless, in long-term inhalation experiment at realistic concentrations, they proved to be of very low systemic toxicity and negligible pulmonary fibrogenicity. This paradox may be explained by low $\mathrm{SiO}_{2}$ retention in lungs and other organs due to a relatively high solubility of these nanoparticles in relevant biological and model milieus.

However, their genotoxic action and transnasal penetration into the brain found in the same inhalation experiment should make one give a cautious overall assessment of this aerosol as an occupational or environmental hazard.

\section{Acknowledgements}

The research was partially supported by the Ministry of Science and Higher Education of the Russian Federation (project 3.9534.2017/8.9) and by Government of the Russian Federation (Act 211, Agreement 02.A03.21.0006). The equipment of the Ural Centre for Shared Use "Modern Nanotechnology" UrFU was used.

\section{References}

[1] Du Z J, Zhao D L, Jing L, Cui G, Jin M, Li Y, Liu X, Liu Y, Du H, Guo C, Zhou X and Sun Z 2013 Cardiovascular toxicity of different sizes amorphous silica nanoparticles in rats after intratracheal instillation Cardiovasc. Toxicol. 13 194-207

[2] Eom H J and Choi J 2009 Oxidative stress of silica nanoparticles in human bronchial epithelial cell, Beas-2B Toxicol. In Vitro 23 1326-32

[3] Guo C, Xia Y, Niu P, Jiang L, Duan J, Yu Y, Zhou X, Li Y and Sun Z 2015 Silica nanoparticles induce oxidative stress, inflammation, and endothelial dysfunction in vitro via activation of the MAPK/Nrf2 pathway and nuclear factor- $\kappa B$ signaling Int. J. Nanomed. 10 1463-77

[4] Guo C, Yang M, Jing 1, Wang J, Yu Y, Li Y, Duan J, Zhou X, Li Y and Sun Z 2016 Amorphous silica nanoparticles trigger vascular endothelial cell injury through apoptosis and autophagy via reactive oxygen species-mediated MAPK/Bcl-2 and PI3K/Akt/mTOR signaling Int. J. Nanomed. 11 5257-76

[5] Kim Y J, Yu M, Park H O and Yang S I 2010 Comparative study of cytotoxicity, oxidative stress and genotoxicity induced by silica nanomaterials in human neuronal cell line Mol. Cell. Toxicol. 6 336-43

[6] Park E J and Park K 2009 Oxidative stress and pro-inflammatory responses induced by silica nanoparticles in vivo and in vitro Toxicol. Lett. 184 18-25

[7] Petrick L, Rosenblat M, Paland N and Aviram M 2016 Silicon dioxide nanoparticles increase macrophage atherogenicity: stimulation of cellular cytotoxicity, oxidative stress, and 
triglycerides accumulation Environ. Toxicol. 31 713-23

[8] Sergent J A, Paget V and Chevillard S 2012 Toxicity and genotoxicity of nano- $\mathrm{SiO}_{2}$ on human epithelial intestinal HT-29 cell line Ann. Occup. Hyg. 56 622-30

[9] Wang J, Yu Y, Lu K, Yang M, Li Y, Zhou X and Sun Z 2017 Silica nanoparticles induce autophagy dysfunction via lysosomal impairment and inhibition of autophagosome degradation in hepatocytes Int. J. Nanomed. 12 809-25

[10] Bellmann B, Creutzenberg O and Dasenbrock C 1991 Lung clearance and retention of toner utilizing a tracer technique, during chronic inhalation exposure in rats Fund. Appl. Toxicol. 17 300-13

[11] Oberdörster G, Sharp Z, Atudore V, Elder A, Gelein R and Kreylin W 2004 Translocation of inhaled ultrafine particle to the brain Inhal. Toxicol. 16 437-45

[12] Elder A, Gelein R, Silva V, Feikert T, Opanashuk L, Carter J, Potter R, Maynard A, Ito Y, Finkelstein J and Oberdörster G 2006 Translocation of inhaled ultrafine manganese oxide particles to the central nervous system Environ. Health Perspect. 114 1172-8

[13] Kao Y-Y, Cheng T-J, Yang D-M and Liu P-Sh 2012 Demonstration of an olfactory bulb-brain translocation pathway for $\mathrm{ZnO}$ nanoparticles in rodent ells in vitro and in vivo $\mathrm{J}$. Mol. Neurosci. 48 464-71

[14] Sutunkova M P, Katsnelson B A, Privalova L I, Gurvich V B, Konysheva L K, Shur V Ya, Shishkina E V, Minigalieva I A, Solovjeva S N, Grebenkina S V and Zubarev I V 2016 On the contribution of the phagocytosis and the solubilization to the iron oxide nanoparticles retention in and elimination from lungs under long-term inhalation exposure Toxicol. 363 1928 